\title{
Distribution of Metals in the Waters and Sediments of Rivers in Central Amazon Region, Brazil
}

\author{
Isabela C. Constantino, ${ }^{a}$ Grazielly C. Teodoro, ${ }^{a}$ Altair B. Moreira, ${ }^{a}$ \\ Fabiana M. M. Paschoal, ${ }^{b}$ Wanderson G. Trindade ${ }^{b}$ and Márcia C. Bisinoti ${ }^{\circledR * a}$ \\ ${ }^{a}$ Instituto de Biociências, Letras e Ciências Exatas, Universidade Estadual Paulista (Unesp), \\ Campus de São José do Rio Preto, Rua Cristovão Colombo, 2265, \\ 15054-000 São José do Rio Preto-SP, Brazil \\ ${ }^{b}$ Instituto de Ciências Exatas e Tecnologia, Universidade Federal do Amazonas (UFAM), \\ Campus de Itacoatiara, Rua Nossa Senhora do Rosário, 3863, 69103-128 Itacoatiara-AM, Brazil
}

Seasonal concentrations of total, particulate and dissolved $\mathrm{Al}, \mathrm{Cu}, \mathrm{Cd}, \mathrm{Cr}, \mathrm{Fe}, \mathrm{Pb}$ and $\mathrm{Ni}$ were analyzed in surface water and total metals in sediment samples from black and whitewater rivers within the Itacoatiara City, Central Amazon. Metals concentrations in water and sediment samples demonstrated that even though urbanization and agricultural practices are common in this region. Metal concentrations in sediments samples are acceptable regarding the recommended levels for protection of aquatic life. From this work, which is the first trace elements study in the main tributaries from Itacoatiara region, we conclude that metals are present in a particulate form, being easier to be transported to other aquatic bodies. During flooding periods an increase of $\mathrm{Al}, \mathrm{Fe}$ and total organic compound (TOC) in almost water sampling points was observed.

Keywords: Amazon, metal biogeochemistry, blackwater, whitewater, sediment

\section{Introduction}

The Amazon region is a biome of global importance, given its scale and biodiversity. The region has the largest hydrographic basin in the world, with substantial rivers and numerous flood areas that can provide considerable organic matter (OM), soil nutrients and metals for the aquatic system. In the Amazon, three types of waters can be identified: whitewaters with near-neutral $\mathrm{pH}$ and that contain large amounts of particulates; blackwaters that are acidic and rich in organic matter; and clear waters that have physicochemical characteristics between white and blackwater rivers. ${ }^{1-3}$

Amazonas River is among the world's largest in terms of drainage area $\left(6 \times 10^{6} \mathrm{~km}^{2}\right)$, with $20 \%$ of the flow of water from the land to the ocean. Itacoatiara is the third most populous municipality in the State of Amazonas, with an area of $8,891,906 \mathrm{~km}^{2}$ and a hot, rainy and humid climate. Itacoatiara is located on the left bank of the Amazonas River, having a thermoelectric as the main electric power source. This region is deemed to be one of the largest agricultural centers in Northern Brazil and is also an important fluvial

*e-mail: marcia.bisinoti@unesp.br port for cargo transportation and tourism. The main activities include agriculture (particularly cassava, bananas, corn, orange, beans, coffee and vegetables), as well as fishing and equine, cattle and pig rearing. In this region, there are several aquatic bodies representative of white and blackwaters that flow into the Amazonas River.

The metals may have a lithogenic origin, resulting from bedrock weathering or from anthropogenic activities such as the use of fertilizers, pesticides, domestic effluent, steel industry and/or atmospheric deposition. ${ }^{4,5}$ These elements can be classified as essential and non-toxic ( $\mathrm{Ca}$ and $\mathrm{Mg}$ ), essential but toxic in high concentrations ( $\mathrm{Fe}, \mathrm{Mn}, \mathrm{Zn}, \mathrm{Cu}$, $\mathrm{Co}, \mathrm{Ni}$ and $\mathrm{Mo}$ ), or toxic $(\mathrm{Pb}, \mathrm{Hg}$ and $\mathrm{Cd}) .{ }^{6}$ Several studies of metal transport have been conducted in the Amazon region, but most have been centered on the main rivers, especially the Negro, Solimões, Madeira and Amazonas River. ${ }^{2,3,7-13}$ Considering the land use in this region and since the Amazon River carries annually around 600 million tons of sediment to the ocean, the evaluation of metals transportation in the main tributaries of white and blackwaters from under-investigated regions are of great relevance to monitor the vulnerability of aquatic life and because these shall contribute to a significant fraction of metals exported to the ocean. This study aimed 
determination of total, dissolved and particulate metals concentration in freshwater and sediments of the rivers from Central Brazilian Amazon.

\section{Experimental}

\section{Study area}

This study was conducted in the region of Central Amazon basin. Water samples were collected during two expeditions (November 2015, dry period; July 2016, rainy period), while sediment was collected only in the former. In total, surface water samples were collected at 15 sampling sites (see Figure 1), being 5 representatives of whitewater and other 10 samples collected in the blackwater rivers (Table 1) (sampling authorization of SISBIO No. 50042-2). The sampling sites were selected based on the history of the use and occupation of the soil in the region and its animal husbandry activities. November 2015 represented the dry season, marked by approximately $70 \mathrm{~mm}$ of monthly rainfall, while July 2016 was representative of the rainy period, with $120 \mathrm{~mm}$ of rainfall. ${ }^{14}$

The sampling of surface sediment was also carried out at nine locations in November 2015 (Figure 1); it was not possible to collect at all sites due to the depths of some of the rivers. Sediment samples were collected using an Ekman-Birge dredger $(30 \times 30 \mathrm{~cm})$. Samples for metal determination were stored in plastic bags. All samples were refrigerated and then taken to the laboratory of UNESP at São José do Rio Preto City (São Paulo State) for analysis.
The water samples were collected at $30 \mathrm{~cm}$ depth, in triplicate, at each of the sampling sites according to recommendations of National Guide for Sampling and Preservation of Samples. ${ }^{15}$ Water samples for total organic carbon (TOC) quantification were collected in an amber glass bottle $(250 \mathrm{~mL})$, and the water samples for metals quantification were collected in polyethylene terephthalate (PET) plastic bottles $(250 \mathrm{~mL})$, previously decontaminated in a $10 \% \mathrm{v} / \mathrm{v}$ nitric acid bath. Total, dissolved and particulate metal were analyzed in all water samples. Dissolved metal (DM) was defined as the metal quantified in the water samples filtered on a $0.45 \mu \mathrm{m}$ (cellulose membrane), total metal (TM) was associated as the water samples (not filtered) and submitted to digestion followed by the recommendations of the EPA method 3005A. ${ }^{16}$ Particulate metal (PM) was obtained by the difference between TM and DM. Preparation and preservation procedures of samples were carried out in the laboratory of Federal University of Amazonas (Itacoatiara City).

Physico-chemical analysis and metals determination

\section{Surface water samples}

Measurements of $\mathrm{pH}$, electrical conductivity (EC), color, dissolved oxygen (OD), temperature (T) and turbidity were undertaken in the field in the aquatic body, using multiparameter equipment (Hanna/HI991300 for $\mathrm{pH} / \mathrm{CE} /$ STD/T, Hanna/HI96727C for color, Hanna/HI9146-04 for OD and Hanna/HI93703C for turbidity, Sălaj, Romania).

Table 1. Localization of the sampling sites in the blackwater and whitewater rivers in this study

\begin{tabular}{|c|c|c|c|}
\hline River & Water type & Sampling site ID & Coordinate \\
\hline Negro & blackwater & 1 & $3^{\circ} 04^{\prime} 13.74^{\prime \prime S} 60^{\circ} 08^{\prime} 26.92^{\prime \prime} \mathrm{W}$ \\
\hline Madeira & whitewater & 2 & $3^{\circ} 30^{\prime} 14.2^{\prime \prime} \mathrm{S} 58^{\circ} 53^{\prime} 56.3^{\prime \prime} \mathrm{W}$ \\
\hline Urubu 4 & blackwater & 3 & $2^{\circ} 59^{\prime} 15.9^{\prime \prime} \mathrm{S} 58^{\circ} 27^{\prime} 12.7^{\prime \prime} \mathrm{W}$ \\
\hline Anebá & blackwater & 4 & $2^{\circ} 57^{\prime} 58.5^{\prime \prime} \mathrm{S} 58^{\circ} 29^{\prime} 51.5^{\prime \prime} \mathrm{W}$ \\
\hline Urubu 3 & blackwater & 5 & $3^{\circ} 00^{\prime} 33.1^{\prime \prime S} 58^{\circ} 34^{\prime} 13.5^{\prime \prime} \mathrm{W}$ \\
\hline Carú 2 & blackwater & 6 & $3^{\circ} 02^{\prime} 21.7^{\prime \prime S} 58^{\circ} 37^{\prime} 27.9^{\prime \prime} \mathrm{W}$ \\
\hline Carú 1 & blackwater & 7 & $3^{\circ} 01^{\prime} 11.0^{\prime \prime S} 58^{\circ} 34^{\prime} 57.4^{\prime \prime} \mathrm{W}$ \\
\hline Urubu 2 & blackwater & 8 & $3^{\circ} 03^{\prime} 17.3^{\prime \prime} \mathrm{S} 58^{\circ} 34^{\prime} 28.8^{\prime \prime} \mathrm{W}$ \\
\hline Urubu 1 & blackwater & 9 & $3^{\circ} 01^{\prime} 52.1^{\prime \prime} \mathrm{S} 58^{\circ} 34^{\prime} 29.2^{\prime \prime} \mathrm{W}$ \\
\hline Amazonas 1 & whitewater & 10 & $3^{\circ} 14^{\prime} 34.8^{\prime \prime S} 58^{\circ} 33^{\prime} 13.4^{\prime \prime} \mathrm{W}$ \\
\hline Amazonas 2 & whitewater & 11 & $3^{\circ} 09^{\prime} 05.6^{\prime \prime S} 58^{\circ} 24^{\prime} 15.5^{\prime \prime} \mathrm{W}$ \\
\hline Amazonas 3 & whitewater & 12 & $3^{\circ} 13^{\prime} 15.0^{\prime \prime} \mathrm{S} 58^{\circ} 18^{\prime} 20.2^{\prime \prime} \mathrm{W}$ \\
\hline Arari & whitewater & 13 & $3^{\circ} 34^{\prime} 24.9^{\prime \prime} \mathrm{S} 58^{\circ} 22^{\prime} 13.5^{\prime \prime} \mathrm{W}$ \\
\hline Paraconi & blackwater & 14 & $3^{\circ} 51^{\prime} 24.0^{\prime \prime S} 58^{\circ} 19^{\prime} 19.8^{\prime \prime} \mathrm{W}$ \\
\hline Igarapé Caiaué & blackwater & 15 & $4^{\circ} 02^{\prime} 27.8^{\prime \prime} \mathrm{S} 58^{\circ} 25^{\prime} 18.4^{\prime \prime} \mathrm{W}$ \\
\hline
\end{tabular}




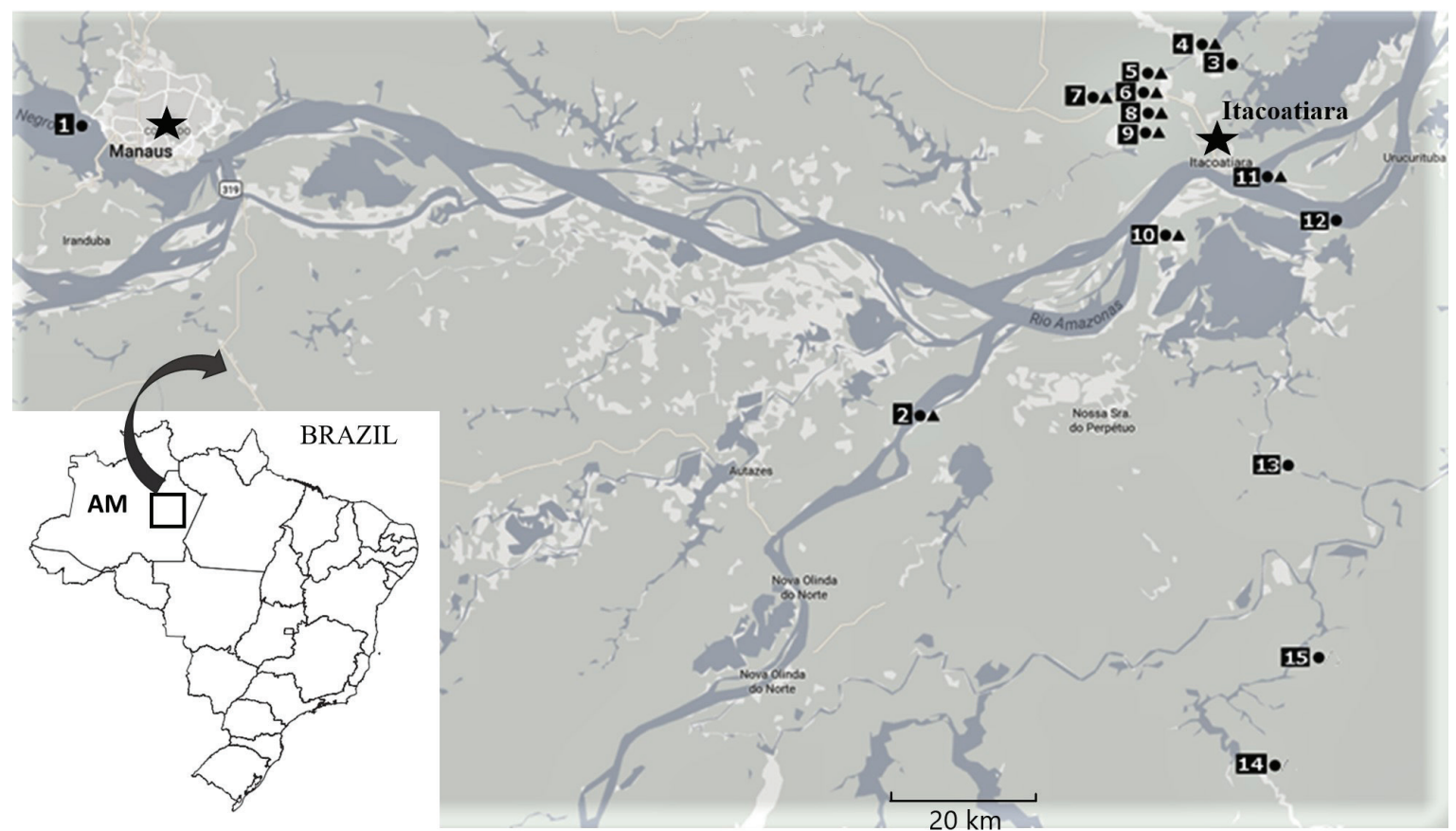

Figure 1. Location of sampling sites of surface water (-) and sediments( $(\boldsymbol{\Delta})$ in the Amazon basin: (1) Negro, (2) Madeira, (3) Urubu 4, (4) Anebá, (5) Urubu 3, (6) Carú 2, (7) Carú 1, (8) Urubu 2, (9) Urubu 1, (10) Amazonas 1, (11) Amazonas 2, (12) Amazonas 3, (13) Arari, (14) Paraconi and (15) Igarapé Caiaué.

TOC analysis was performed using an organic carbon analyzer (TOC-VCSN, Shimadzu, Japan).

Total and dissolved metal were quantified using graphite furnace atomic absorption spectrometry (GFAAS) (with Zeeman background corrector) (AA280Z, Varian,

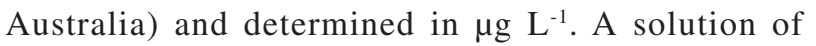
$\mathrm{Pd} / \mathrm{Mg}\left(\mathrm{NO}_{3}\right)_{2}$ (ratio $1500 / 1000 \mathrm{mg} \mathrm{L}^{-1}$ ) was used as the chemical modifier in the atomization process to determine the $\mathrm{Cu}, \mathrm{Cd}, \mathrm{Cr}, \mathrm{Pb}, \mathrm{Fe}$ and $\mathrm{Ni}$ elements. The instrumental parameters of lamp, monochromator crack and detection wavelength $\mathrm{Al}(10.0 \mathrm{~mA}, 0.5 \mathrm{~nm}$ and $396.2 \mathrm{~nm}), \mathrm{Cu}(4.0 \mathrm{~mA}, 0.5 \mathrm{~nm}$ and $327.4 \mathrm{~nm})$, $\mathrm{Cd}(5.0 \mathrm{~mA}, 0.5 \mathrm{~nm}$ and $228.8 \mathrm{~nm}), \mathrm{Cr}(7.0 \mathrm{~mA}, 0.2 \mathrm{~nm}$ and $357.9 \mathrm{~nm}), \mathrm{Fe}(5.0 \mathrm{~mA}, 0.2 \mathrm{~nm}$ and $248.3 \mathrm{~nm})$, $\mathrm{Pb}(10.0 \mathrm{~mA}, 0.5 \mathrm{~nm}$ and $283.3 \mathrm{~nm})$ and $\mathrm{Ni}(10.0 \mathrm{~mA}$, $0.2 \mathrm{~nm}$ and $232.0 \mathrm{~nm}$ ) were used. The limits of detection (LOD) determined for each element were: $\mathrm{Al}: 0.73 \mu \mathrm{g} \mathrm{L}^{-1}$, $\mathrm{Cu}: 0.74 \mu \mathrm{g} \mathrm{L}{ }^{-1}, \mathrm{Cd}: 0.07 \mu \mathrm{g} \mathrm{L}{ }^{-1}, \mathrm{Cr}: 0.83 \mu \mathrm{g} \mathrm{L}^{-1}$, Fe: $3.21 \mu \mathrm{g} \mathrm{L}^{-1}$, Pb: $2.22 \mu \mathrm{g} \mathrm{L}{ }^{-1}$, Ni: $0.37 \mu \mathrm{g} \mathrm{L}^{-1}$.

\section{Sediment samples}

The organic matter $(\mathrm{OM})$ content of the sediment samples was determined via differences in mass following the calcination $\left(4 \mathrm{~h}\right.$ at $\left.750{ }^{\circ} \mathrm{C}\right)$ of the dried samples. Elemental analysis of $\mathrm{C}, \mathrm{H}$ and $\mathrm{N}$ of the sediment samples was performed using an elemental analyzer (CE Instruments, model EAGER 200), for this the sediments were dried and homogenized. A granulometric analysis was conducted by sieving and pipette method. ${ }^{17}$
The sediment samples were wet-decomposed following the 3050B method. ${ }^{18}$ Quantification of the total elements $\mathrm{Al}, \mathrm{Cu}, \mathrm{Cr}, \mathrm{Fe}, \mathrm{Pb}, \mathrm{Ni}$ and $\mathrm{Zn}$ in the digested samples were determined using an atomic absorption spectrophotometer with flame atomization (FAAS, AA240FS, Varian, Australia) or atomic absorption with graphite furnace atomization (AA280Z, Varian, Australia). The conditions for Cr quantified by GFAAS were the same previously described for water samples ("Physico-chemical analysis and metals determination" sub-section, "Surface water samples" sub-sub-section). FAAS was employed using the following conditions: $\mathrm{Al}(10.0 \mathrm{~mA}, 0.5 \mathrm{~nm}$ and $309.3 \mathrm{~nm})$, $\mathrm{Cu}(4.0 \mathrm{~mA}, 0.5 \mathrm{~nm}$ and $324.8 \mathrm{~nm}), \mathrm{Fe}(5.0 \mathrm{~mA}, 0.2 \mathrm{~nm}$ and $248.3 \mathrm{~nm}), \mathrm{Pb}(10.0 \mathrm{~mA}, 1.0 \mathrm{~nm}$ and $217.0 \mathrm{~nm})$ and $\mathrm{Ni}(10.0 \mathrm{~mA}, 0.2 \mathrm{~nm}$ and $232.0 \mathrm{~nm})$ and $\mathrm{Zn}(5.0 \mathrm{~mA}$, $1.0 \mathrm{~nm}$ and $213.9 \mathrm{~nm}$ ). The limits of detection determined for each element were: $\mathrm{Al}: 0.04 \mathrm{mg} \mathrm{L}^{-1}, \mathrm{Cu}: 0.28 \mathrm{mg} \mathrm{L}^{-1}$, Fe: $0.04 \mathrm{mg} \mathrm{L}^{-1}, \mathrm{~Pb}: 0.04 \mathrm{mg} \mathrm{L}^{-1}$, Ni: $0.07 \mathrm{mg} \mathrm{L}^{-1}$, $\mathrm{Zn}: 0.01 \mathrm{mg} \mathrm{L}^{-1}$. The concentration of the elements was determined in $\mathrm{mg} \mathrm{kg}^{-1}$ or $\mathrm{g} \mathrm{kg}^{-1}$ considering the mass employed in the initial digestion process.

Quality control/assurance for the analysis of metals in water and sediment samples

Analytical quality control for the quantification of metals in water and sediment samples by GFAAS and FAAS were based on the use of certified reference material (1640a NIST® SRM®, trace elements in natural water) 
and the recoveries ranged from 90 to $110 \%$. The laboratory has been participated in a proficiency assays carried out by Brazilian Agricultural Research Corporation (EMBRAPA) for samples of vegetal tissues and animal food. All results were considered very good, receiving the designation of satisfactory $(\mathrm{z}<2)$.

\section{Statistical analysis}

An exploratory analysis of the obtained data set (total metal concentration, TOC, OD and $\mathrm{pH}$ ) was conducted using principal component analysis (PCA). ${ }^{19}$ The $\mathrm{X}$ matrix was autoscaled, and the scores and loadings were calculated using MATLAB 2017b. ${ }^{20}$

\section{Results and Discussion}

\section{Surface water samples: characterization and seasonality}

The values determined for the $\mathrm{pH}$, conductivity, temperature, TOC concentration, turbidity, color and dissolved oxygen of the samples collected during the dry and rainy periods are presented in Table 1 . The $\mathrm{pH}$ of the water samples in the dry period ranged from 4.7 to 6.85 for the blackwater rivers and from 7.26 to 7.30 for the whitewater rivers, in accordance with the classification of these waters. The OD values also varied between the dry and rainy seasons, the lowest value being observed for the Carú 1 River in the rainy season. At the other sites, OD values were above the minimum recommended by Brazilian legislation, ${ }^{21} 5.0 \mathrm{mg} \mathrm{L}^{-1}$, with the exception of Urubu 1 (4.6 mg L $\left.{ }^{-1}\right) .{ }^{22}$ The Brazilian legislation establishes the maximium values for some chemical elements to guarantee the safety use of the water. The classification of the water sources vary from special (high quality), and from 1 to 4 (quality is decreasing). These classes define uses for protection of springs, water supply after treatment, animal watering, irrigation, landscape harmony, navigation, among others. All surface water rivers of the sampled region in the Amazon are considered class 2 with destination for protection of aquatic communities, recreation of primary contact, irrigation, fishing activity among others.

An increase in TOC concentrations was observed for the samples collected during the rainy season, with the exception of the Madeira River sample (Table 2). In the rainy season, the blackwater rivers demonstrated greater TOC than the whitewater rivers. Increased TOC concentrations during flood periods was also observed in studies conducted for other rivers located in tropical forests, as well as in temperate regions and more northerly latitudes. ${ }^{23-25}$ In these studies, alongside increased dissolved organic carbon (DOC) concentrations, higher concentrations were observed for lignin $(\Sigma 8)$, indicating that a direct relationship exists with the hydrological cycle. Indeed, during periods of flood, organic material leached from the surface layers of the soil due to the decomposition of leaf litter is incorporated.

Turbidity values for whitewaters and blackwaters ranged from 40.7 to 86.0 and 0.24 to 9.46 , respectively. The highest values were found for whitewaters and (Madeira and Amazonas rivers). These results were expected because whitewaters rivers are known to contain higher amount of suspended particulated material (SPM) due to their powerful currents, which promote the resuspension of the bottom sediments and provide them with a muddy appearance. ${ }^{1}$ In the present study most of the metals (approximately 70\%) are present in the particulate fraction (PM). It is expected whitewaters would be responsible for higher transportation of metals in the watershed.

Overall, the results obtained are in accordance with another Amazon freshwater studies. ${ }^{2,11}$ Total $\mathrm{Cr}, \mathrm{Ni}, \mathrm{Cd}$, $\mathrm{Cu}, \mathrm{Pb}, \mathrm{Fe}$ and $\mathrm{Al}$ concentrations varied as described in Table 3: in the dry period, the total $\mathrm{Cr}$ concentrations were $<2.78 \mu \mathrm{g} \mathrm{L} \mathrm{L}^{-1}$ for most of locations, except for whitewater rivers Amazonas 1 and Madeira, 7.67 and $10.29 \mu \mathrm{g} \mathrm{L}{ }^{-1}$, respectively, and for blackwater rivers Anebá and Urubu 2, with concentrations of 13.15 and $5.58 \mu \mathrm{g} \mathrm{L}^{-1}$, respectively.

In the rainy season, a decline in the concentration of $\mathrm{Cr}$ for the Amazonas 1 and Madeira sites was observed (Table 3). In the case of total Ni, in all of the aquatic bodies the concentrations were lower than the limit of quantification (LOQ) of the employed method $\left(1.22 \mu \mathrm{g} \mathrm{L}^{-1}\right)$ and DM smaller than that recommended by Brazilian legislation, ${ }^{21}$ aside from the sampling sites in the Amazonas 1 and Madeira (5.41 and $8.75 \mu \mathrm{g} \mathrm{L}^{-1}$ ) during the dry season ( $43.9 \%$ in the particulate metal fraction for Amazonas 1 and $76.7 \%$ for Madeira). It should be noted that during the rainy season, one point was sampled along the Amazonas River (Amazonas 3) and this was the sole location to present higher values $\left(7.16 \mu \mathrm{g} \mathrm{L}^{-1}\right)$ than that observed for Amazonas 1 (Itacoatiara) and Amazonas 2 (downstream of Itacoatiara). Dissolved Cd concentrations were all lower than the values recommended by Brazilian legislation, ${ }^{21}$ both in the dry and rainy season.

$\mathrm{Cu}$ concentrations for the samples obtained during the dry period were below the LOQ for all the locations, except for the Madeira River (TM 5.68 $\mu \mathrm{g} \mathrm{L}{ }^{-1}$ and DM $3.44 \mu \mathrm{g} \mathrm{L}^{-1}$ ). However, there was an increase in $\mathrm{Cu}$ at the points sampled during the rainy season, indicating that they are from diffuse sources, potentially associated with the use of copper as a fungicide in the region's agricultural activities, or even from the soil itself. It is significant that the highest values were 
Table 2. Values of $\mathrm{pH}$, temperature, total organic carbon, turbidity, color and dissolved oxygen in surface water samples collected during dry and rainy periods in aquatic bodies of black and whitewater in the region of the study

\begin{tabular}{|c|c|c|c|c|c|c|}
\hline Sampling site & $\mathrm{pH}$ & Temperature $/{ }^{\circ} \mathrm{C}$ & $\mathrm{TOC} /\left(\mathrm{mg} \mathrm{L}^{-1}\right)$ & Turbidity & Color & $\mathrm{OD} /\left(\mathrm{mg} \mathrm{L}^{-1}\right)$ \\
\hline \multicolumn{7}{|l|}{ Dry season } \\
\hline Carú 1 (river) & 5.35 & 29.5 & 2.93 & - & - & 6.6 \\
\hline Carú 2 (river) & 4.7 & 27.7 & 3.71 & - & - & 6.7 \\
\hline Anebá (river) & 4.80 & 31.3 & 2.20 & - & - & 6.5 \\
\hline Urubu 1 (river) & 6.54 & 32.1 & 2.67 & - & - & 5.6 \\
\hline Urubu 2 (river) & 6.40 & 32.1 & 2.59 & - & - & 5.6 \\
\hline Urubu 3 (river) & 6.00 & 31.6 & 1.98 & - & - & 5.5 \\
\hline Urubu 4 (river) & 6.85 & 31.3 & 2.56 & - & - & 5.6 \\
\hline Amazonas 1 (river) & 7.26 & 31.1 & 2.48 & - & - & 6.3 \\
\hline Amazonas 2 (river) & 7.27 & 31.3 & 3.80 & - & - & 6.0 \\
\hline Madeira (river) & 7.30 & 31.9 & 1.83 & - & - & 6.4 \\
\hline \multicolumn{7}{|l|}{ Rainy season } \\
\hline Carú 1 (river) & 6.25 & 26.4 & 6.37 & 2.57 & 130.0 & 4.9 \\
\hline Carú 2 (river) & 6.40 & 30.9 & 6.70 & 1.24 & 135.0 & 6.3 \\
\hline Anebá (river) & 6.86 & 30.6 & 6.70 & 0.97 & 115 & 6.7 \\
\hline Urubu 1 (river) & 5.87 & 28.2 & 6.91 & 9.46 & 240 & 7.3 \\
\hline Urubu 2 (river) & 5.86 & 28.9 & 6.67 & 9.33 & 230 & 5.8 \\
\hline Urubu 3 (river) & 5.70 & 24.7 & 6.65 & 8.69 & 216.6 & 5.3 \\
\hline Urubu 4 (river) & 6.20 & 27.8 & 6.50 & 8.23 & 203.3 & 4.6 \\
\hline Amazonas 1 (river) & 6.20 & 29.4 & 3.31 & 63.0 & 353.3 & 6.1 \\
\hline Amazonas 2 (river) & 6.3 & 28.9 & 5.36 & 40.7 & 313.3 & 5.8 \\
\hline Amazonas 3 (river) & 7.13 & 28.4 & 3.01 & 86.0 & 415.0 & 7.3 \\
\hline Madeira (river) & 6.11 & 31.6 & 1.84 & 62.3 & 34.5 & 5.5 \\
\hline Arari (river) & 6.86 & 30.2 & 3.80 & 13.92 & 17.0 & 6.2 \\
\hline Paraconi (river) & 5.61 & 31.5 & 4.33 & 0.63 & 80.0 & 4.1 \\
\hline Igarapé Caiaué & 5.40 & 33.3 & 4.65 & 0.24 & 50.0 & 5.2 \\
\hline Negro (river) & 4.1 & n.d. & 10.37 & n.d. & n.d. & 5.9 \\
\hline Resolução CONAMA 357/2005 (class 2) & 6.0 a 9.0 & n.1. & n.1. & $<100 \mathrm{NTU}$ & n.1. & $>5.0 \mathrm{mg} \mathrm{L}^{-1}$ \\
\hline
\end{tabular}

TOC: total organic carbon; OD: dissolved oxygen; n.d.: parameter not determined; n.l.: parameter not legislated.

observed for the whitewater rivers. Most of the element is present in the particulate fraction.

In the dry period, the highest concentrations of total $\mathrm{Pb}$ were observed for whitewater rivers (Amazonas and Madeira, with 16.38 and $13.66 \mu \mathrm{g} \mathrm{L}^{-1}$, respectively), as well as for blackwater rivers such as Urubu 2 and Urubu 4 (7.84 and $17.59 \mu \mathrm{g} \mathrm{L}{ }^{-1}$, respectively), which are located close to more urbanized areas. The concentration found in the Urubu River can be associated with the thermoelectric. Rainfall is an important source of distribution of metals near from the pollutant source. More than $80 \%$ of the $\mathrm{Pb}$ concentration identified was in particulate form, which may be related to $\mathrm{pH}$ because $\mathrm{Pb}$ ions tend to form precipitates at $\mathrm{pH} 5-9 .{ }^{25} \mathrm{In}$ the rainy season, the concentrations were all lower than the quantification limit of the method employed $\left(<5.66 \mu \mathrm{g} \mathrm{L}^{-1}\right)$ due to the high volume of the water. This finding reinforces the fact that the source of this element is punctual pertinent to the localities in question. In general, the values determined for DM were below the Brazilian legislation, ${ }^{21}$ ensuring the water quality.

$\mathrm{Fe}$ and total $\mathrm{Al}$ concentrations in water samples were observed in the dry and rainy seasons, with certain values exceeding the legislated limits in some localities and these elements are usually naturally present in the soil. ${ }^{2}$ The Fe concentration ranged similiarly with the results previously reported, indicating the concentrations of this element are from natural sources. ${ }^{2}$ Concentrations of total and dissolved $\mathrm{Fe}$ had highest values during the dry period and some sites exceeded the recommended legal values (Table 3). ${ }^{21} \mathrm{Fe}$ concentrations in particulate form ranged from 30 to $90 \%$. 


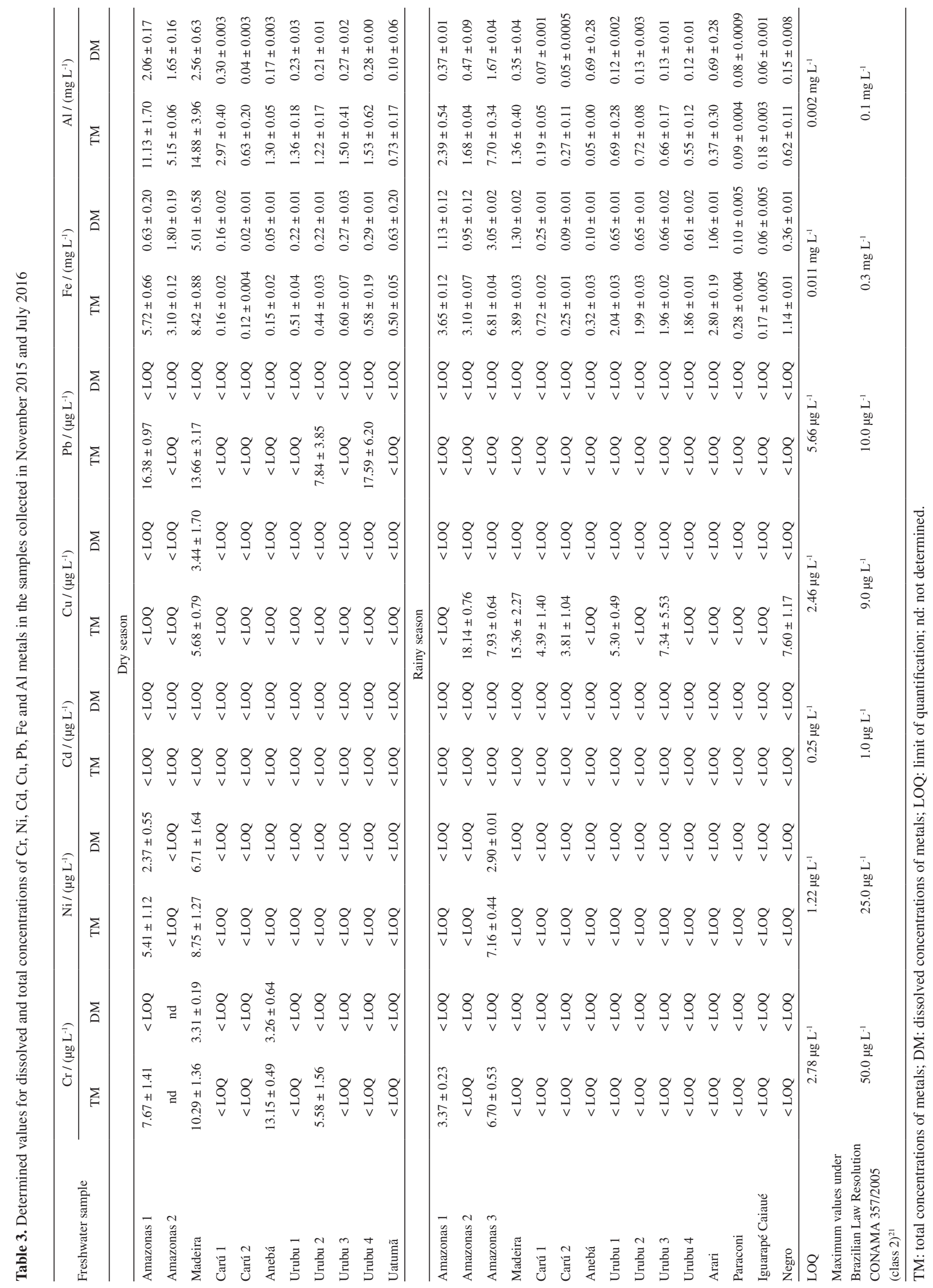


In order to understand the results, multivariate statistical analysis (total metal concentration, TOC, OD and $\mathrm{pH}$ ) was conducted for the two surface water samplings (dry and rainy period). Figures 2 and 3 represent the results.

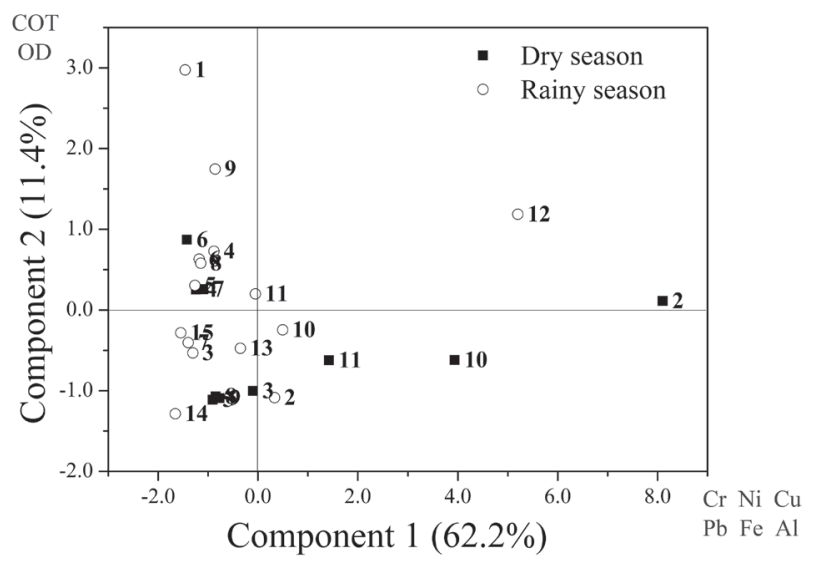

Figure 2. Analysis of the principal components (components 1 and 2) of the metal values and characterization parameters of the white and blackwater samples from 15 sampling sites, obtained during the dry and rainy seasons. Abbreviations used to distinguish surface water samples from periods of drought and rain: (1) Negro; (2) Madeira; (3) Urubu 4; (4) Anebá; (5) Urubu 3; (6) Carú 2; (7) Carú 1; (8) Urubu 2; (9) Urubu 1; (10) Amazonas 1; (11) Amazonas 2; (12) Amazonas 3; (13) Arari; (14) Paraconi; (15) Igarapé Caiaué.

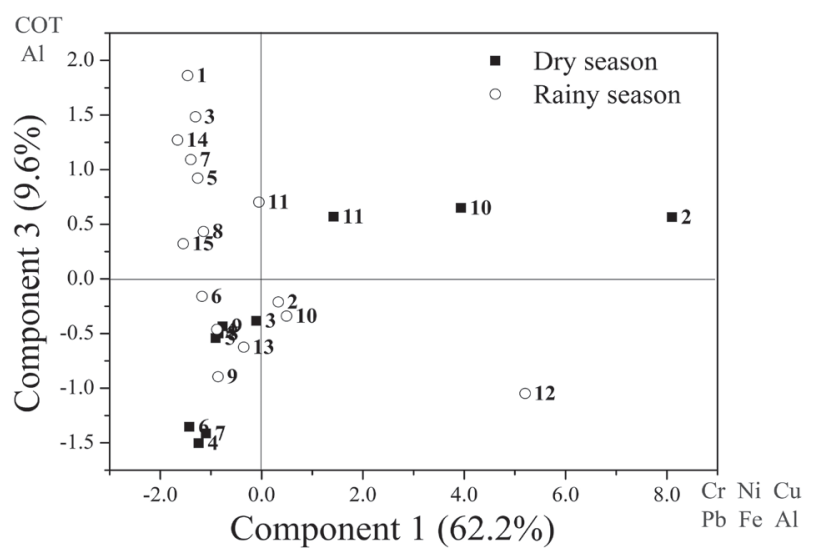

Figure 3. Analysis of principal components (components 1 and 3) of the metal values and characterization parameters of the white and blackwater samples from 15 sampling sites, obtained during the dry and rainy seasons. Abbreviations used to distinguish surface water samples from periods of drought and rain: (1) Negro; (2) Madeira; (3) Urubu 4; (4) Anebá; (5) Urubu 3; (6) Carú 2; (7) Carú 1; (8) Urubu 2; (9) Urubu 1; (10) Amazonas 1; (11) Amazonas 2; (12) Amazonas 3; (13) Arari; (14) Paraconi; (15) Igarapé Caiaué.

Principal components (PC) 1 and 2 of the PCA accounted for $73.6 \%$ of the data variance for the sites sampled during the dry and rainy seasons. This analysis differentiated the samples of blackwater rivers by seasonality, in which axis $y$ explains how $11.4 \%$ of the data were influenced by TOC and OD. A group of samples of whitewater rivers (Amazonas and Madeira) with greater influence of $\mathrm{Fe}, \mathrm{Al}, \mathrm{Cu}, \mathrm{Cr}, \mathrm{Ni}$ and $\mathrm{Pb}(x$ axis, 62.2\%) in both seasons (Amazonas 1, Amazonas 2 and Madeira) could be attributed to the dilution effect caused by the rainy season. However, these sampling sites had little seasonal variation in relation to the TOC concentrations, which may indicate that the presence of these metals was due to anthropogenic action. It should be acknowledged that the Amazonas 3, which is located downstream of Itacoatiara (sample collected only in the rainy season) demonstrated higher concentrations than the other two sites of the Amazonas River. According to information obtained during sampling on both the right and left banks of the Amazonas, soybean and cassava are planted in several regions. However, the differences observed in metal concentrations for these sampling sites can be associated to hydrological events.

In terms of the correlation of $\mathrm{PC} 1$ and $\mathrm{PC} 2$, the TOC parameter had a greater influence on the samples of the blackwater rivers located in Itacoatiara during the rainy season, owing to the leaching effects of the soils. In this sense, it is worth mentioning that the blackwater rivers did not display any variation in increases in $\mathrm{Pb}, \mathrm{Cr}$ and $\mathrm{Ni}$ in the surface water samples (Table 3). For the correlation between PC1 (62.2\%) and PC3 (8.6\%), seasonal variation was more evident for the blackwater river samples, where the TOC and $\mathrm{Al}$ variables exerted greater influence in the rainy season due to the effects of soil runoff (Figure 3).

\section{Sediment samples: physico-chemical parameters and metal determination}

The Table 4 displays the main characteristics of the surface sediment samples of this study, including granulometric composition, $\mathrm{pH}$ and percentages of $\mathrm{OM}$, $\mathrm{C}, \mathrm{N}, \mathrm{H}$ and $\mathrm{S}$. The $\mathrm{pH}$ values determined for the sediment samples ranged from 5.43 to 7.14 .

The majority of the sediments demonstrated a high silt content, in which the silt fraction varied from 65.7 to $91.9 \%$ (Table 4). Furthermore, on these samples the sand content (thin + coarse) ranged from 0.8 to $30.7 \%$ and was most significant in the sediment of whitewater rivers (Amazonas 1 and Madeira). The clay fraction represented the smallest portion in the surface sediments sampled, varying from 3.60 to $9.40 \%$, in which the highest levels of sediment in blackwater rivers were observed. The surface sediments of Amazonas 2 and Madeira were classified as sandy silts, with a granulometric composition predominantly consisting of sand, together with a high silt content and low clay content. The remaining samples were classified as silty; the samples of the Carú and Anebá were particularly rich in silt. The sand content for the Urubu 1 and 3 sites was higher than for the Urubu 2 site, which 
Table 4. Clay, sand and silt contents for surface sediment samples of rivers of the Itacoatiara, AM region

\begin{tabular}{lccccccccc}
\hline & Clay / \% & Sand / $\%$ & Silt / $\%$ & C / $\%$ & H / \% & N / \% & S / \% & OM / \% & $\mathrm{pH}$ \\
\hline Amazonas 1 & 8.10 & 87.92 & 3.98 & 0.35 & 1.51 & $<$ LOD & $<$ LOD & $2.53 \pm 0.03$ & 7.14 \\
Amazonas 2 & 7.18 & 22.45 & 70.37 & 0.92 & 1.43 & $<$ LOD & $<$ LOD & $4.93 \pm 0.11$ & 7.02 \\
Madeira & 3.60 & 30.72 & 65.67 & 0.54 & 1.04 & $<$ LOD & $<$ LOD & $4.55 \pm 0.11$ & 5.43 \\
Carú 1 & 7.33 & 2.40 & 90.27 & 0.26 & 0.86 & $<$ LOD & $<$ LOD & $1.46 \pm 0.11$ & 6.16 \\
Carú 2 & 9.40 & 2.46 & 88.14 & 13.39 & 2.83 & 0.58 & 4.39 & $24.77 \pm 0.00$ & 7.12 \\
Anebá & 7.33 & 0.80 & 91.87 & 11.21 & 2.71 & 0.58 & 4.14 & $27.85 \pm 0.21$ & 5.77 \\
Urubu 1 & 8.09 & 85.79 & 6.12 & 0.43 & 2.14 & $<$ LOD & $<$ LOD & $4.08 \pm 0.18$ & 6.21 \\
Urubu 2 & 8.55 & 5.85 & 85.60 & 0.32 & 1.13 & $<$ LOD & $<$ LOD & $0.63 \pm 0.04$ & 6.28 \\
Urubu 3 & 7.18 & 88.02 & 4.80 & $<$ LOD & $<$ LOD & $<$ LOD & $<$ LOD & $0.25 \pm 0.06$ & 6.57 \\
\hline
\end{tabular}

OM: organic matter; LOD: limit of detection.

could be associated with sampling closer to the bank for those sites or having had the effect of the flooding periods.

The OM contents of the surface sediment samples can be observed in Table 4. The Carú 2 and Anebá rivers sediments presented organic matter contents greater than $20 \%$. The high organic matter content in the Carú 2 and Anebá samples may be related to the fact that they were predominantly silty sediments, composed only of fine particles, to which organic matter can easily associate.

Owing to the lack of Brazilian legislation that addresses the guiding values of metals in sediments not subject to dredging, the determined concentrations of metals will next be compared with the sediment quality guidelines (GVSQ) adopted by the Canadian Council of Ministers of the Environment. ${ }^{26}$ The GVSQ facilitates estimation of whether a contaminant is present in a minimum concentration that has been attributed the occurrence of toxic effects to biota. These values are presented as a threshold effect level (TEL), below which adverse effects to biota rarely occur, or a probable effect level (PEL), above which adverse effects for biota are expected to occur. Table 5 displays the results of metals present in the surface sediment samples collected in November 2015.
All of the analyzed metals presented concentrations lower than the PEL values, indicating that they were below the values associated with probable toxic effects to biota (Table 5). However, attention should be given to some rivers, where the values were close to the TEL limits.

The sediments of the Madeira, Amazonas 1 and 2 presented the highest concentrations of total $\mathrm{Cr}$ that varied from $27.5 \pm 4.3,18.9 \pm 0.2$ and $28.4 \pm 4.5 \mathrm{mg} \mathrm{kg}^{-1}$, respectively, but they were lower of the TEL value $\left(37.3 \mathrm{mg} \mathrm{kg}^{-1} \mathrm{Cr}\right)$. For total $\mathrm{Cu}$ concentrations, the sites mentioned before exhibited also the highest values, in addition of the sediments from blackwaters, Urubu 1 and Anebá (Table 5), but all of them were below TEL value $\left(35.7 \mathrm{mg} \mathrm{kg}^{-1}\right)$. For $\mathrm{Zn}$, all of the samples presented results that were significantly inferior to the value of TEL $\left(123.0 \mathrm{mg} \mathrm{kg}^{-1} \mathrm{Zn}\right)$. The concentration of Al ranged from 0.56 to $57.15 \mathrm{~g} \mathrm{~kg}^{-1}$ for the sediments collected in blackwater rivers, whereas for those collected in whitewater rivers, variation was 13.79 to $132.61 \mathrm{~g} \mathrm{~kg}^{-1}$ (Table 5). In a study carried out in Marajó Bay (Pará, in the eastern portion of the Amazon in Brazil), a possible urban influence on the quality of the bay estuary's sediments were considered. The mean concentrations in the reference area and the urbanized area varied from 20.5 to $20.8 \mathrm{mg} \mathrm{kg}^{-1}$ for $\mathrm{Ni}$, as well as $\mathrm{Cr}$

Table 5. Determined values for total $\mathrm{Pb}, \mathrm{Cr}, \mathrm{Ni}, \mathrm{Al}, \mathrm{Fe}, \mathrm{Cu}$ and $\mathrm{Zn}$ in the surface sediment samples collected in November 2015

\begin{tabular}{lccccccc}
\hline & $\mathrm{Pb} /\left(\mathrm{mg} \mathrm{kg}^{-1}\right)$ & $\mathrm{Cr} /\left(\mathrm{mg} \mathrm{kg}^{-1}\right)$ & $\mathrm{Ni} /\left(\mathrm{mg} \mathrm{kg}^{-1}\right)$ & $\mathrm{Al} /\left(\mathrm{g} \mathrm{kg}^{-1}\right)$ & $\mathrm{Fe} /\left(\mathrm{g} \mathrm{kg}^{-1}\right)$ & $\mathrm{Cu}^{\prime}\left(\mathrm{mg} \mathrm{kg}^{-1}\right)$ & $\mathrm{Zn} /\left(\mathrm{mg} \mathrm{kg}^{-1}\right)$ \\
\hline Amazonas 1 & $9.5 \pm 1.0$ & $18.9 \pm 0.2$ & $10.7 \pm 0.8$ & $13.8 \pm 1.0$ & $6.13 \pm 0.21$ & $13.0 \pm 0.9$ & $24.5 \pm 2.6$ \\
Amazonas 2 & $28.0 \pm 0.6$ & $28.4 \pm 4.5$ & $14.8 \pm 0.3$ & $21.9 \pm 0.1$ & $7.81 \pm 1.86$ & $26.3 \pm 0.5$ & $40.4 \pm 2.6$ \\
Madeira & $15.2 \pm 3.0$ & $27.5 \pm 4.3$ & $17.1 \pm 2.8$ & $132.6 \pm 2.9$ & $13.94 \pm 4.2$ & $26.6 \pm 6.2$ & $49.9 \pm 10.6$ \\
Carú 1 & $19.6 \pm 0.9$ & $19.5 \pm 1.2$ & $6.4 \pm 0.3$ & $45.0 \pm 1.7$ & $1.76 \pm 0.05$ & $<$ LOD & $11.7 \pm 0.4$ \\
Carú 2 & $0.2 \pm 0.3$ & $2.2 \pm 0.1$ & $<$ LOD & $1.2 \pm 0.1$ & $0.04 \pm 0.004$ & $<$ LOD & $0.6 \pm 0.3$ \\
Anebá & $21.1 \pm 4.9$ & $23.4 \pm 5.0$ & $9.0 \pm 0.7$ & $57.1 \pm 0.6$ & $2.21 \pm 0.5$ & $16.0 \pm 0.6$ & $9.7 \pm 2.2$ \\
Urubu 1 & $10.9 \pm 0.3$ & $21.8 \pm 0.7$ & $9.7 \pm 0.0$ & $18.4 \pm 0.4$ & $7.7 \pm 0.25$ & $13.9 \pm 0.3$ & $31.3 \pm 0.5$ \\
Urubu 2 & $2.5 \pm 0.1$ & $2.8 \pm 0.1$ & $1.71 \pm 0.2$ & $2.1 \pm 0.2$ & $0.92 \pm 0.2$ & $<$ LOD & $3.3 \pm 0.9$ \\
Urubu 3 & $1.6 \pm 0.4$ & $1.4 \pm 0.2$ & $<$ LOD & $0.6 \pm 0.02$ & $0.21 \pm 0.02$ & $<$ LOD & $1.2 \pm 0.1$ \\
TEL & 35.0 & 37.3 & n.a. & n.a. & n.a. & 35.7 & 123.0 \\
PEL & 91.3 & 90 & n.a. & n.a. & n.a. & 197.0 & 315.0 \\
\hline
\end{tabular}

LOD: limit of detection; TEL: threshold effect level; PEL probably effect level; n.a.: no GVSQ (sediment quality guidelines) is available for this metal. 
Table 6. Comparison of the maximum and minimum values for metals in sediments samples of this study and other fluvial system in the North of Brazil

\begin{tabular}{|c|c|c|c|c|c|c|c|c|}
\hline Sediment sample & $\begin{array}{c}\mathrm{Pb} / \\
\left(\mathrm{mg} \mathrm{kg}^{-1}\right) \\
\end{array}$ & $\begin{array}{c}\mathrm{Cr} / \\
\left(\mathrm{mg} \mathrm{kg}^{-1}\right) \\
\end{array}$ & $\begin{array}{c}\mathrm{Ni} / \\
\left(\mathrm{mg} \mathrm{kg}^{-1}\right) \\
\end{array}$ & $\begin{array}{c}\mathrm{Al} / \\
\left(\mathrm{g} \mathrm{kg}^{-1}\right)\end{array}$ & $\begin{array}{c}\mathrm{Fe} / \\
\left(\mathrm{g} \mathrm{kg}^{-1}\right) \\
\end{array}$ & $\begin{array}{c}\mathrm{Cu} / \\
\left(\mathrm{mg} \mathrm{kg}^{-1}\right)\end{array}$ & $\begin{array}{c}\mathrm{Zn} / \\
\left(\mathrm{mg} \mathrm{kg}^{-1}\right) \\
\end{array}$ & Ref. \\
\hline Whitewater rivers & $9.5-28.0$ & $18.9-28.4$ & $10.7-17.1$ & $13.8-132.6$ & $1.1-2.0$ & $13.0-26.6$ & $24.5-49.9$ & this study \\
\hline Blackwater rivers & $0.2-21.1$ & $1.4-23.4$ & $<$ LOD $^{\mathrm{a}}-9.7$ & $0.6-57.1$ & $0.1-1.5$ & $<$ LOD $^{\mathrm{a}}-16.0$ & $0.6-31.3$ & this study \\
\hline $\begin{array}{l}\text { Xingu River under urban } \\
\text { influence (Pará) }\end{array}$ & $6.9-29.3$ & $9.5-46.8$ & $2.97-22.93$ & - & - & $1.95-21.55$ & - & Ribeiro et al. ${ }^{11}$ \\
\hline $\begin{array}{l}\text { Xingu River less antrophic } \\
\text { influence (Pará) }\end{array}$ & $2.87-4.78$ & $9.32-9.34$ & $1.74-3.10$ & - & - & $0.83-2.52$ & - & Ribeiro et al. ${ }^{11}$ \\
\hline $\begin{array}{l}\text { Reference area - Furo of Laura } \\
\text { (Marajó Bay, Pará) }\end{array}$ & - & $53.1-62.8$ & $19.0-21.9$ & $9.1-14.9$ & $27.0-37.6$ & $11.7-15.1$ & - & Lima et al. ${ }^{10}$ \\
\hline $\begin{array}{l}\text { Under urbanization area - } \\
\text { Furo of Laura (Marajó Bay, Pará) }\end{array}$ & - & $55.9-63.2$ & $19.1-22.9$ & $9.6-14.5$ & $28.2-32.4$ & $12.4-15.0$ & - & Lima et al. ${ }^{10}$ \\
\hline Puruzinho Lake (Amazonas) & $8.2-15.5$ & $6.8-19.3$ & - & - & $8.5-28.9$ & $4.1-16.4$ & $17.9-113.9$ & Carvalho et al. ${ }^{9}$ \\
\hline
\end{tabular}

aLimit of detection.

and $\mathrm{Cu}$ concentrations did not change (57.2 to $58.6 \mathrm{mg} \mathrm{kg}^{-1}$, and 13.0 to $13.8 \mathrm{mg} \mathrm{kg}^{-1}$, respectively), indicating that these elements occur naturally. ${ }^{9}$ However, the concentrations determined in the present study were higher and varied among the sampling sites, indicating anthropogenic influence on the contents of $\mathrm{Zn}, \mathrm{Cu}, \mathrm{Ni}, \mathrm{Cr}$ and $\mathrm{Pb}$.

The determination of metals in the surface sediments of the Amazonas River (Amazonas 1 and 2) near Itacoatiara region provides evidence that the sampling points closest to the urbanized areas presented higher $\mathrm{Pb}, \mathrm{Cr}, \mathrm{Ni}, \mathrm{Cu}$ and $\mathrm{Zn}$ contents, which may be of anthropogenic origin. Superior concentrations of these elements in relation to Amazonas 1 (upstream of Itacoatiara) and Amazonas 2 (downstream of Itacoatiara) can be observed. For the surface water samples, $\mathrm{Pb}$ was only quantified in the dry period and exhibited in higher concentrations at Amazonas 1 and Madeira. The quantified values for surface water samples from these points also indicate that most of these elements were not in dissolved form, influenced by the $\mathrm{pH}$ of these aquatic bodies and the presence of TOC, and so the tendency was for these elements to be deposited in the sediments. Although $\mathrm{Cu}$ and $\mathrm{Zn}$ are essential for biological organisms, in excess, they are considered toxic and can have significant consequences for biota. ${ }^{27}$ Generally, the results found in this work are comparable with the ones obtained by other studies carried out in sediments from North of Brazil present in fluvial system under antrophic activities (Table 6).

Figure 4 displays the results of the PCA for the sediment samples. The first two axes of the PCA explained $69.6 \%$ of the values for the sites sampled. PCA 1 represented $40.4 \%$ of the data variance and PC2 29.2\%. The sediments of the whitewater rivers (Amazonas and Madeira) were influenced by the presence of $\mathrm{Cr}, \mathrm{Ni}, \mathrm{Al}, \mathrm{Fe}, \mathrm{Cu}, \mathrm{Zn}$ and silt. The other locations were representative of sediment in blackwater rivers and did not show any influence of the above variables, although the presence of silt and the elemental composition (C, H, N, S) was identifiable. Therefore, the whitewater rivers as well as the sediment coming from sampling site 1 of the Urubu River displayed potential anthropogenic influence due to the accumulation of $\mathrm{Cr}, \mathrm{Ni}, \mathrm{Al}, \mathrm{Fe}, \mathrm{Cu}, \mathrm{Zn}$.

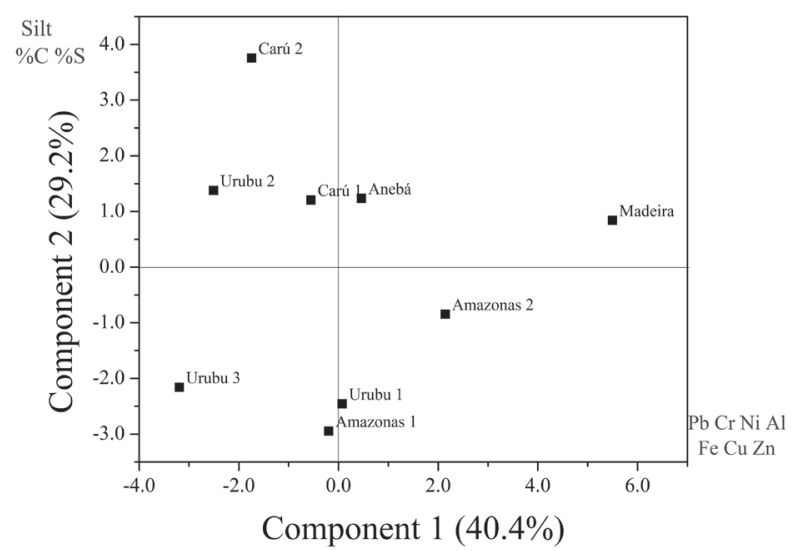

Figure 4. Principal component analysis (components 1 and 2) of the metal values and basic characterization parameters of sediment samples from white- and blackwaters of the Central Amazon.

\section{Conclusions}

This study evaluated the concentrations of metals in the surface waters and sediments of the rivers from the Itacoatiara region, Central Brazilian Amazon, as well the distribution and transportation of metals. The results suggest that the sampled sites are still preserved from metal contamination. However, some locations indicate potential anthropogenic influence in terms of the presence of $\mathrm{Cu}, \mathrm{Cr}, \mathrm{Ni}$ and $\mathrm{Pb}$ in the water, being these sites near to the more urbanized areas, including the site 1 in the Urubu River and sites Amazonas 2 and Amazonas 3 (which are both downstream of Itacoatiara) as well as the Madeira. The seasonality effect was evident from the PCA, enabling us to infer that 
the blackwaters are affected by TOC and Al, consequence of the runoff in the rainy period, whereas the whitewaters are distinguished by $\mathrm{Fe}, \mathrm{Al}, \mathrm{Cu}, \mathrm{Cr}, \mathrm{Ni}$ and $\mathrm{Pb}$. It is also worth noting that approximately $70 \%$ of the metals present are in particulate form, hence it would appear that most are transported, implying the contribution of tributaries to the Amazonas River and subsequently to the ocean. The analysis of metals in the sediments prompted the same conclusions, highlighting these elements potential to accumulate, albeit within the limits recommended by legislation. Therefore, these environments can be considered uncontaminated and serve as reference areas for comparison.

\section{Acknowledgments}

The authors are grateful for the financial support received from São Paulo Research Foundation (FAPESP, project 2015/22954-1 and 2018/15733-7) and the financial support of Brazilian National Council for Scientific and Technological Development (CNPq, project 457865/2014-8). The authors are also grateful to Prof Dr Edenir R. Pereira-Filho for PCA calculations using Matlab 2017b and for the valuable contributions of the reviewers.

\section{References}

1. Junk, W. J.; Wittmann, F.; Schöngart, J.; Piedade, M. T. F.; Wetlands Ecol. Manage. 2015, 23, 677.

2. Horbe, A. M. C.; Oliveira, L. G. de S.; Acta Amazonica 2008, $38,753$.

3. Horbe, A. M. C.; Santos, A. G. S.; J. Braz. Chem. Soc. 2009, $20,1119$.

4. Malavolta, E.; Fertilizantes e seu Impacto Ambiental: Micronutrientes e Metais Pesados, Mitos, Mistificação, e Fatos; ProduQuímica: São Paulo, 1994.

5. de Jesus, H. C.; Costa, E. A.; Mendonça, A. S. F.; Zandonade, E.; Quim. Nova 2004, 27, 378.

6. Valls, M.; de Lorenzo, V.; FEMS Microbiol. Rev. 2002, 26, 327.

7. Lacerda, L. D.; Paula, F. C. F.; Ovalle, A. R. C.; Pfeiffer, W. C.; Malm, O.; Sci. Total Environ. 1990, 97/98, 525.

8. Benedetti, M. F.; Mounier, S.; Filizola, N.; Benaim, J.; Seyler, P.; Hydrol. Processes 2003, 17, 1363.

9. Carvalho, D. P.; de Almeida, R.; Manzatto, A. G.; de Freitas, O. B.; Bastos, W. R.; Rev. Bras. Recur. Hídricos 2018, 23, e21.

10. Lima, M. W.; Santos, M. L. S.; Faial, K. C. F.; Freitas, E. S.; Lima, M. O.; Pereira, J. A. R.; Cunha, I. P. R. T.; Mar. Pollut. Bull. 2017, 118, 403.

11. Ribeiro, D. R. G.; Faccin, H.; Molin, T. R. D.; Carvalho, L. M. C.; Amado, L. L.; Sci. Total Environ. 2017, 605-606, 66.

12. Bisinoti, M. C.; Sargentini Jr., E.; Jardim, W. F.; J. Braz. Chem. Soc. 2007, 18, 544.
13. Jardim, W. F.; Bisinoti, M. C.; Fadini, P. S.; Silva, G. S.; Aquat. Geochem. 2010, 16, 267.

14. http://www.inmet.gov.br/portal/index.php?r=tempo2/ mapasPrecipitacao, accessed in May 2019.

15. Companhia Ambiental do Estado de São Paulo (CETESB); Agência Nacional de Águas (ANA); Guia Nacional de Coleta e Preservação de Amostras: Água, Sedimento, Comunidades Aquáticas e Efluentes Líquidos; CETESB: São Paulo; ANA: Brasília, 2011; available at http:// arquivos.ana.gov.br/institucional/sge/CEDOC/Catalogo/2012/ GuiaNacionalDeColeta.pdf, accessed in May 2019.

16. USEPA Method 3005A: Acid Digestion of Waters for Total Recoverable or Dissolved Metals for Analysis by FLAA or ICP Spectroscopy; USEPA: USA, 1992; available at https://www. epa.gov/sites/production/files/2015-12/documents/3005a.pdf, accessed in May 2019.

17. Kairyte, M.; Stevens, R. L.; Mar. Geol. 2009, 257, 87.

18. USEPA Method 3050B: Acid Digestion of Sediments, Sludge and Soils; USEPA: USA, 1996; available at https://www.epa. gov/sites/production/files/2015-06/documents/epa-3050b.pdf, accessed in May 2019.

19. Wold, S.; Esbensen, K.; Geladi, P.; Chemom. Intell. Lab. Syst. 1987, 2, 37.

20. The MathWorks, Inc.; MATLAB 2017b; The MathWorks, Inc., Natick, MA, USA, 2017.

21. Conselho Nacional do Meio Ambiente (CONAMA); Resolução CONAMA No. 357/2005, de 17 de março de 2005; Dispõe sobre a Classificação dos Corpos de Água e Diretrizes Ambientais para o seu Enquadramento, bem como Estabelece as Condições e Padrões de Lançamento de Efluentes, e Dá Outras Providências; Diário Oficial da União (DOU), 2005, No. 053, p. 58-63; available at http://www2.mma.gov.br/port/ conama/legiabre.cfm?codlegi=459, accessed in May 2019.

22. Coynel, A.; Seyler, P.; Etcheber, H.; Meybeck, M.; Orange, D.; Global Biogeochem. Cycles 2005, 19, GB4019.

23. Spencer, R. G. M.; Hernes, P. J.; Ruf, R.; Baker, A.; Dyda, R. Y.; Stubbins, A.; Six, J.; J. Geophys. Res.: Biogeosci. 2010, 115, G03013.

24. Striegl, R. G.; Dornblaser, M. M.; Aiken, G. R.; Wickland, K. P.; Raymond, P. A.; Water Resour. Res. 2007, 43, 2001.

25. Martín-Torre, M. C.; Payán, M. C.; Verbinnen, B.; Coz, A.; Ruiz, G.; Vandecasteele, C.; Viguri, J. R.; Arch. Environ. Contam. Toxicol. 2015, 68, 577.

26. http://ceqg-rcqe.ccme.ca/en/index.html\#void, accessed in May 2019.

27. Ribeiro, C. A. O.; Vollaire, Y.; Sanchez-Chardi, A.; Roche, H.; Aquat. Toxicol. 2005, 74, 53.

Submitted: November 2, 2018

Published online: May 20, 2019 